\title{
Molecular Diversity of Rhizobacteria in Ginseng Soil and Their Plant Benefiting Attributes
}

\author{
Eun Hye Hong ${ }^{1}$, Sun Hee Lee ${ }^{1}$, Regupathy Thamizh Vendan ${ }^{2}$, and Young Ha Rhee ${ }^{1 *}$ \\ ${ }^{I}$ Department of Microbiology \& Molecular Biology, Chungnam National University, Daejeon 305 764, Republic of Korea \\ ${ }^{2}$ Agricultural College \& Research Institute, Tamil Nadu Agricultural University, Tiruchirappalli -620 009 Tamil Nadu, India

\section{인삼토양 내 근권세균의 다양성 및 식물에의 유용 특성}

\author{
홍은혜 $^{1} \cdot$ 이선희 ${ }^{1} \cdot$ 알 타미즈 벤단 ${ }^{2} \cdot$ 이영하 $^{1 *}$ \\ ${ }^{1}$ 충남대학교 생명시스템과학대학 미생물· 분자생명과학과 \\ ${ }^{2}$ 인도 타밀나두 농업대학교
}

(Received October 2, 2012 / Accepted December 14, 2012)

\begin{abstract}
The purpose of this study was to investigate the molecular diversity of rhizobacteria associated with ginseng of varying age levels and their plant benefiting attributes. A total of 143 different isolates belonging to 15 different bacterial genera were recovered. Although variation was found in the rhizobacterial community due to age of the plant, majority of bacteria belong to Firmicutes (58\%). In which, Bacillus was found to be the predominant genus imespective of age of the ginseng. To assess the plant benefiting attributes, 30 representative isolates were selected. The results indicated that some of the isolates could exhibit multiple plant growth promoting traits like secretion of cell wall degrading enzymes, production of indole-3-acetic acid, synthesis of siderophores, solubilization of phosphates and soil pathogens inhibition. It can be suggested that strains of $B$. subtilis, $B$. amyloliquefaciens, $B$. velezensis, and $B$. licheniformis were positive for all the above traits, which have potential to be used as plant growth promoting inoculants to improve ginseng crop in the future.
\end{abstract}

Keywords: diversity, ginseng, plant growth promoting rhizobacteria (PGPR), rhizobacteria

The screening and using of specific rhizobacteria to promote plant growth and to control plant diseases continue to be an area of rapidly expanding research. Rhizosphere microorganisms, which are closely associated with roots, have been termed plant growth promoting rhizobacteria (PGPR). It includes a diverse group of free-living soil bacteria that can colonize plant roots actively and improve host plant growth and development. Several mechanisms have been suggested by which PGPR can promote plant growth including phytohormone production, $\mathrm{N}_{2}$ fixation, stimulation of nutrient uptake and biocontrol of pathogenic microorganisms (Vessey, 2003; Banchio et al., 2008). Significant increases in growth and yield of agronomical important crops in response to inoculation with PGPR have been reported (Bashan et al., 2004; Noura et al., 2008; Yang et al., 2009; Lee et al., 2012).

Ginseng (Panax ginseng C.A. Meyer) has been regarded as one of the important remedies in oriental medicine for more

*For correspondence. E-mail: yhrhee@cnu.ac.kr; Tel.: +82-42-821-6413; Fax: +82-42-822-7367 than thousand years (Yu et al., 2003). Ginseng is presently used as a health tonic, and in adaptogenic, antiaging, prophylactic, and restorative remedies. In general, growth of high quality ginseng requires at least 4 years of cultivation under shade condition. In view of the widespread application of rhizobacteria in ginseng, studies on the molecular diversity of plant growth promoting rhizobacteria coupled with their plant benefiting attributes are necessary. The aims of the present study were (i) to analyze the molecular diversity of rhizobacterial community of ginseng plants of varying age levels and (ii) to assess the selected isolates for the plant benefiting attributes viz., cell wall degrading enzyme activity, indole-3-acetic acid (IAA) production, siderophore secretion, phosphate solubilization and soil pathogens inhibition.

\section{Materials and Methods}

\section{Isolation of rhizobacteria from ginseng}

The diversity of rhizobacteria was estimated from the rhizosphere soil of one year to three year-old ginseng plants 
maintained at Okcheon, Korea. To isolate rhizobacteria, $5 \mathrm{~g}$ of ginseng rhizosphere soil samples were suspended in $45 \mathrm{ml}$ of phosphate buffered saline ( $\mathrm{pH}$ 7.2). Serial dilutions were prepared and spread on tryptic soy agar (TS, Difco, USA), nutrient agar (NS, Difco) and malt extract agar (MS, Difco) and the plates were examined for growth after incubation at $30^{\circ} \mathrm{C}$ for $48 \mathrm{~h}$.

\section{DNA extraction and 16S rRNA gene analysis}

The isolated rhizobacteria were cultured in nutrient broth at $30^{\circ} \mathrm{C}$ for $24 \mathrm{~h}$ and then centrifuged at $14,000 \times g$ for $5 \mathrm{~min}$ at $4^{\circ} \mathrm{C}$. The pellet was subjected to DNA extraction using the G-spin $^{\mathrm{TM}}$ Genomic DNA Extraction Kit (iNtRON Biotechnology, Korea). To amplify the 16S rRNA genes, the polymerase chain reaction (PCR) was performed with the universal primers 27F and 1492R (Bai et al., 2002). The PCR consisted of a $95^{\circ} \mathrm{C}$ hold for $5 \mathrm{~min}$, followed by 35 cycles of 30 sec at $95^{\circ} \mathrm{C}, 30 \mathrm{sec}$ at $50^{\circ} \mathrm{C}, 30 \mathrm{sec}$ at $72^{\circ} \mathrm{C}$, and a final extension for $7 \mathrm{~min}$ at $72^{\circ} \mathrm{C}$. The amplification was performed using a PE2400 thermal cycler (Perkin Elmer, USA). The PCR fragment was purified by using a QIAquick PCR Purification kit (QIAGEN, USA).

Sequencing was performed on an ABI Prism 3730 DNA analyzer (Applied Biosystems, USA) by using an ABI BigDye cycle sequencing kit (Applied Biosystems) with EF-Taq DNA polymerase (Solgent, Korea). All reference sequences were obtained from the National Centre for Biotechnology Information (NCBI) and Ribosomal Database Project (RDP) databases. The $16 \mathrm{~S}$ rRNA similarity sequences searches were performed using the BLASTN tool in the NCBI website (McGinnis and Madden, 2004). Sequences were aligned by using the multiple sequence alignment program, CLUSTAL W (Tompson et al., 1994). Phylogenetic analysis was performed using MEGA 4.0 software (Tamura et al., 2007). Neighbor-joining method was employed to infer the tree topology. The reliability of the trees was tested by bootstrapping 1,000 replicates generated with a random seed. The matrix distances were calculated based on $p$-distance.

\section{Assay of cell wall degrading enzymes}

To detect extracellular protease, cellulase and xylanase from ginseng rhizobacteria, the agar diffusion method was used. The isolates were grown on protease activity indicator medium [LB medium containing $0.5 \%(\mathrm{w} / \mathrm{v})$ skim milk and $1.5 \%$ agar (w/v)] for protease activity detection. The isolates were grown on cellulase activity indicator medium [LB medium containing $0.5 \%$ carboxylmethylcellulose $(\mathrm{w} / \mathrm{v})$ and $1.5 \%$ agar $(\mathrm{w} / \mathrm{v})]$ for cellulase activity detection. The isolates were grown on xylanase activity indicator medium [LB medium containing $0.5 \%$ oat spelt xylan (w/v) and $1.5 \%$ agar (w/v)] for xylanase activity detection. To visualize the halos formed due to cellulase and xylanase activity, the plates were flooded with $0.5 \%$ Congo red solution for $30 \mathrm{~min}$, rinsed with water, and then washed twice with $1 \mathrm{M} \mathrm{NaCl}$. Isolates positive for extracellular cellulase and xylanase activities were surrounded by a yellow halo against a red background.

\section{Assay on the production of IAA, siderophores and} solubilization of phosphates

IAA production was estimated by growing the isolates in nutrient broth supplemented with $200 \mu \mathrm{g} / \mathrm{ml}$ of tryptophan at $30^{\circ} \mathrm{C}$ with shaking for $48 \mathrm{~h}$ in dark. Twenty-five $\mathrm{ml}$ of the sample was withdrawn and the cells were spun down at 5,000 rpm for $15 \mathrm{~min}$. The filtrate was adjusted to $\mathrm{pH} 3.0$ using $2 \mathrm{~N} \mathrm{HCl}$ and evaporated in a vacuum evaporator. The residue was dissolved in $2 \mathrm{ml}$ methanol and added to $1.5 \mathrm{ml}$ of distilled water in a test tube. Four $\mathrm{ml}$ of fresh Salper reagent was rapidly added and kept in complete darkness for $1 \mathrm{~h}$ prior to reading of the absorbance at $535 \mathrm{~nm}$ (Hartmann et al., 1983). The capacity of the rhizobacteria for the production of siderophore was assessed by the Chrome azurol S (CAS) method (Schwyn and Neilands, 1987). Siderophore production of the ginseng bacterial isolates was observed through the color change in the CAS blue medium. Mineral phosphate solubilization activity was qualitatively assayed on dicalcium phosphate plates (Goldstein, 1986) by the observation of a distinct zone of clarification around the colonies after $48 \mathrm{~h}$ of incubation at $30^{\circ} \mathrm{C}$.

\section{Antifungal activity against pathogens}

The isolated rhizobacteria were spotted on the middle of half side of PDA and then a mycelial disc ( $5 \mathrm{~mm}$ in diameter) of the plant pathogen from the margin of growing culture was placed at the center of the opposite side. The antifungal activity was surveyed against four plant pathogenic fungi; Fusarium oxysporum, Phytophthora capsici, Rhizoctonia solani, and Phythium ultimum. After incubation for 7 days at $28^{\circ} \mathrm{C}$, inhibition of mycelial growth of each fungus was rated as following: -, not inhibited; +, weakly inhibited; ++ , moderately inhibited; and +++, strongly inhibited (Lee et al., 2003).

\section{Nucleotide sequence accession numbers}

The 16S rRNA gene sequences of bacterial isolates obtained in this study have been submitted to the GenBank database and assigned accession numbers from JN993703 to JN993732.

\section{Results}

Isolation of culturable rhizobacteria from ginseng rhizosphere

We have isolated several rhizobacteria from the rhizosphere 
Table 1. Similarity values of 16S rRNA gene sequences from the rhizobacteria of ginseng soil

\begin{tabular}{|c|c|c|c|}
\hline Isolate $^{\mathrm{a}}$ & Closest relative (accession number) ${ }^{b}$ & Similarity $^{\mathrm{c}}$ & Phylum \\
\hline TSI-2 & Bacillus koreensis (AY667496.1) & 100.0 & Firmicutes \\
\hline TSI-7 & Paenibacillus pabuli (DQ288948.1) & 99.3 & Firmicutes \\
\hline TSI-14 & Bacillus velezensis (EU852930.1) & 100.0 & Firmicutes \\
\hline MSI-1 & Arthrobacter oxydans (GU332595.1) & 99.6 & Actinobacteria \\
\hline MSI-6 & Bacillus velezensis (EU852930.1) & 99.8 & Firmicutes \\
\hline MSI-9 & Bacillus subtilis (EU931563.1) & 99.8 & Firmicutes \\
\hline MSI-11 & Arthrobacter nicotinovorans (GQ284331.1) & 99.6 & Actinobacteria \\
\hline MSI-15 & Paenibacillus polymyxa (GU332610.1) & 99.4 & Firmicutes \\
\hline NSI-1 & Bacillus amyloliquefaciens (HM055610.1) & 99.5 & Firmicutes \\
\hline NSI-6 & Arthrobacter nicotinovorans (GQ284333.1) & 99.6 & Actinobacteria \\
\hline NSI-7 & Bacillus megaterium (EU931553.1) & 99.9 & Firmicutes \\
\hline TSII-7 & Bacillus pumilus (EU379281.1) & 99.7 & Firmicutes \\
\hline TSII-8 & Paenibacillus barcinonensis (DQ363432.1) & 99.4 & Firmicutes \\
\hline TSII-13 & Bacillus bataviensis (EU334358.1) & 98.8 & Firmicutes \\
\hline TSII-18 & Streptomyces mexicanus (EU334358.1) & 98.8 & Actinobacteria \\
\hline MSII-6 & Bacillus pumilus (GU726861.1) & 99.8 & Firmicutes \\
\hline MSII-10 & Bacillus amyloliquefaciens (HM055610.1) & 99.8 & Firmicutes \\
\hline MSII-14 & Paenibacillus polymyxa (EU362603.1) & 98.8 & Firmicutes \\
\hline NSII-3 & Streptomyces lincolnensis (GQ258686.1) & 99.1 & Actinobacteria \\
\hline NSII-11 & Bacillus amyloliquefaciens (HM055610.1) & 99.8 & Firmicutes \\
\hline NSII-15 & Bacillus mycoides (GU171377.1) & 99.6 & Firmicutes \\
\hline NSII-16 & Bacillus subtilis (HM149534.1) & 99.6 & Firmicutes \\
\hline TSIII-14 & Paenibacillus alvei (AB377108) & 99.3 & Firmicutes \\
\hline MSIII-3 & Bacillus megaterium (HM103348) & 99.6 & Firmicutes \\
\hline NSIII-5 & Microbacterium foliorum (EU714341) & 99.5 & Actinobacteria \\
\hline NSIII-7 & Bacillus mycoides (FJ544336) & 99.2 & Firmicutes \\
\hline NSIII-8 & Bacillus pumilus (FJ763643) & 99.9 & Firmicutes \\
\hline NSIII-10 & Bacillus amyloliquefaciens (FJ889054) & 99.9 & Firmicutes \\
\hline NSIII-11 & Bacillus licheniformis (GU323372) & 98.7 & Firmicutes \\
\hline NSIII-20 & Bacillus shandongensis (EU046267) & 99.8 & Firmicutes \\
\hline
\end{tabular}

${ }^{a}$ TS,MS, NS denote the media used; I-III denotes the age of the plant (1 to 3 years) followed by the number indicating the representative isolate

${ }^{\mathrm{b}}$ Closest relative species and its accession number in the 16S rRNA gene sequence database

${ }^{c}$ Per cent similarity of the sequence in BLAST result

soil taken from one year to three year old ginseng plants with the help of three different growth media. Based on the colony growth and morphology, the bacteria were screened at random and purified. The screened isolates were designated according to the media used and the age of the plant source (TS I, TS II, TS III, NS I, NS II, NS III, MS I, MS II, and MS III). A total number of 143 colonies were isolated from the rhizosphere soil of ginseng plants of varied age levels (data shown only for thirty selected isolates) (Table 1). The nucleotide sequences of 16S rRNA genes of the isolates were determined and aligned with those of reference strains in GenBank. All the isolates showed high similarities (>99\%) with their closest related species. They predominantly belonged to the genus Bacillus followed by Arthrobacter and Streptomyces. The vast prevalence of the genus Bacillus was found in all soil samples irrespective of the age of ginseng.

\section{Phylogenetic analyses of the isolates}

The phylogenetic tree showing the relationships between the isolates and related reference species is depicted in Fig. 1. The results of phylogenetic analysis could discriminate four clusters: Firmicutes, Actinobacteria, $\beta$-Proteobacteria, and $\gamma$-Proteobacteria. The cluster Firmicutes comprises Gram-positive bacteria with low $\mathrm{G}+\mathrm{C}$ content was the most dominant group among the clusters. The genus Bacillus was found to be the major one (83 of 143 isolates) in this cluster followed by Paenibacillus and Lysinibacillus. Next to Firmicutes, Actinobacteria was found to occur in all soil samples which included mainly Arthrobacter 
and Streptomyces. Few numbers of Burkholderia and a Cupriavidus belonged to the third cluster, $\beta$-Proteobacteria, which were seen only in the two years old ginseng plant rhizosphere. Each number of Pseudomonas lini, P. frederiksbergensis, and Dyella japonica of $\gamma$-Proteobacteria were found in one year and two year old ginseng soil samples. No bacterial isolate was found from both the Proteobacterial clusters in the three year old ginseng rhizosphere.

\section{Assessment of plant benefiting attributes}

The cell wall degrading ability of thirty numbers of screened rhizobacteria was investigated, specifically protease, cellulase and xylanase were assayed (Table 2). Except four isolates, all the isolates displayed protease activity. The isolate NS II-15 (Bacillus mycoides) showed higher activity. Nearly half of the isolates did not exhibit cellulase activity. MS I-15 (Paenibacillus polymyxa) and NS II-16 (Bcaillus subtilis) demonstrated higher cellulase activity among the isolates studied. Xylanase activity was observed in almost all the isolates except in four isolates. The isolate NS II-15 ( $B$. mycoides) exhibited higher activity of not only protease but also xylanase.

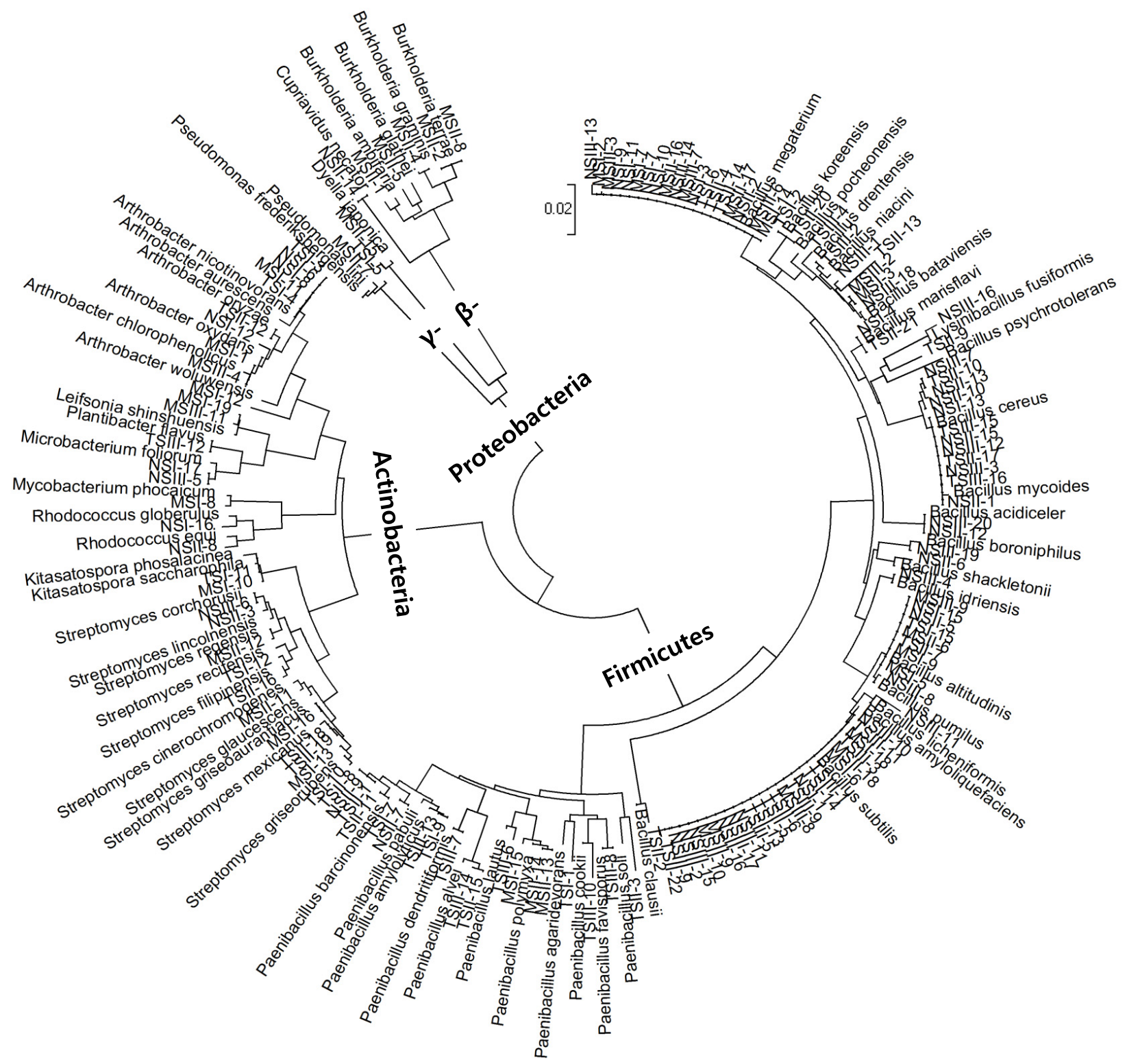

Fig. 1. Phylogenetic tree based on $16 \mathrm{~S}$ rDNA sequences of the rhizobacteria of the ginseng soil and other related genera using neighbor-joining method. Bootstrap analyses were performed with 1,000 repetitions and results are represented at the radiation. 
Table 2. Identification of the cell wall degrading enzyme activity, IAA production, siderophore production, and phosphate solubilization ability from the rhizobacteria of the ginseng soil

\begin{tabular}{|c|c|c|c|c|c|c|c|}
\hline Isolate & Closest relative & $\begin{array}{l}\text { Protease } \\
(\mathrm{mm})^{\mathrm{a}}\end{array}$ & $\begin{array}{c}\text { Cellulase } \\
(\mathrm{mm})^{\mathrm{a}}\end{array}$ & $\begin{array}{c}\text { Xylanase } \\
(\mathrm{mm})^{\mathrm{a}}\end{array}$ & IAA $(\mu \mathrm{M})$ & $\begin{array}{l}\text { Siderophore } \\
\text { Production- } \\
\text { Color change }\end{array}$ & $\underset{\text { solubilization }^{\mathrm{b}}}{\mathrm{P}}$ \\
\hline TSI-2 & Bacillus koreensis & 14 & - & 20 & 228.8 & + & + \\
\hline TSI-7 & Paenibacillus pabuli & 5 & 17 & 14 & 50.6 & - & + \\
\hline TSI-14 & Bacillus velezensis & 22 & 22 & 29 & 15.1 & + & + \\
\hline MSI-1 & Arthrobacter oxydans & 10 & 24 & 15 & 24.5 & + & + \\
\hline MSI-6 & Bacillus velezensis & 18 & 19 & 15 & 30.1 & - & ++ \\
\hline MSI-9 & Bacillus subtilis & 14 & 21 & 7 & 31.4 & - & ++ \\
\hline MSI-11 & Arthrobacter nicotinovorans & 15 & - & 18 & 27.6 & - & ++ \\
\hline MSI-15 & Paenibacillus polymyxa & 13 & 25 & 8 & 15.8 & - & + \\
\hline NSI-1 & Bacillus amyloliquefaciens & 20 & - & 19 & 15.9 & + & + \\
\hline NSI-6 & Arthrobacter nicotinovorans & 16 & - & 13 & 12.7 & - & ++ \\
\hline NSI-7 & Bacillus megaterium & 17 & - & 9 & 11.4 & - & ++ \\
\hline TSII-7 & Bacillus pumilus & 13 & 19 & 27 & 22.7 & - & + \\
\hline TSII-8 & Paenibacillus barcinonensis & - & 14 & - & 70.6 & - & + \\
\hline TSII-13 & Bacillus bataviensis & 5 & - & - & 29.2 & - & + \\
\hline TSII-18 & Streptomyces mexicanus & - & 16 & 23 & 55.6 & - & - \\
\hline MSII-6 & Bacillus pumilus & 12 & 20 & 20 & 29.4 & + & + \\
\hline MSII-10 & Bacillus amyloliquefaciens & 18 & 21 & 30 & 14.7 & + & ++ \\
\hline MSII-14 & Paenibacillus polymyxa & 9 & 20 & - & 39.5 & - & - \\
\hline NSII-3 & Streptomyces lincolnensis & - & - & 5 & 10.7 & - & - \\
\hline NSII-11 & Bacillus amyloliquefaciens & 17 & 18 & 20 & 30.6 & + & + \\
\hline NSII-15 & Bacillus mycoides & 29 & - & 45 & 44.0 & - & - \\
\hline NSII-16 & Bacillus subtilis & 16 & 25 & 25 & 33.1 & + & + \\
\hline TSIII-14 & Paenibacillus alvei & 8 & - & - & 127.9 & - & - \\
\hline MSIII-3 & Bacillus megaterium & 13 & - & 10 & 50.2 & + & ++ \\
\hline NSIII-5 & Microbacterium foliorum & - & - & 8 & 5.8 & + & - \\
\hline NSIII-7 & Bacillus mycoides & 13 & - & 21 & 69.1 & + & + \\
\hline NSIII-8 & Bacillus pumilus & 12 & 20 & 16 & 13.4 & - & - \\
\hline NSIII-10 & Bacillus amyloliquefaciens & 21 & 23 & 15 & 7.6 & + & + \\
\hline NSIII-11 & Bacillus licheniformis & 11 & 22 & 10 & 16.7 & + & + \\
\hline NSIII-20 & Bacillus shandongensis & 15 & - & 18 & 122.5 & + & - \\
\hline
\end{tabular}

${ }^{\mathrm{a}}$ The enzyme activity was expressed as a halo zone formed around the colonies

${ }^{\mathrm{b}}$ Symbol:,-+ and ++ indicate no $(<1 \mathrm{~mm})$, moderate $(1-3 \mathrm{~mm})$ and strong $(>3 \mathrm{~mm}$ in clarification zone $)$ activity, respectively.

All the isolates have the ability to produce IAA in considerable amount (Table 2). The isolate B. koreensis (TS I-2) recorded the maximum amount of $228.8 \mu \mathrm{M}$ of IAA in nutrient broth. Only 14 isolates produced siderophore, as evidenced by the change of colour in the CAS medium from bluish green to orange (Table 2). More number of isolates derived from third year old ginseng rhizosphere soil were found to produce siderophore when compared to one and two years old ginseng soil samples. We examined all the screened isolates for their phosphate solubilizing ability. Out of 30 isolates, 22 isolates showed detectable amount of solubilization (Table 2). In contrast to siderophore production, isolates obtained from rhizosphere of one and two years old ginseng plants recorded more phosphate solubilization.

Selected rhizobacteria from the ginseng rhizosphere of varied age levels were studied to determine their in vitro inhibitory activity against $F$. oxysporum, $P$. capsici, $R$. solani, and P. ultimum (Table 3). Most of the isolates appeared to have poor to moderate antifungal activity against the phytopathogens tested. The isolates, B. amyloliquefaciens (NS I-1) and $B$. subtilis (NS II-16) exhibited moderate inhibitory activity against all pathogens tested except $R$. solani. The rhizobacterial isolates of B. amyloliquefaciens (NS II-11, MS II-10, and NS III-10) had moderate antifungal activity against $F$. oxysporum 
Table 3. In vitro inhibitory activity against the phytopathogens by ginseng rhizobacteria

\begin{tabular}{|c|c|c|c|c|c|}
\hline Isolate & Closest relative & F. oxysporum & P. capsici & R. solani & P. ultimum \\
\hline TSI-2 & Bacillus koreensis & & & & \\
\hline TSI-7 & Paenibacillus pabuli & & & & + \\
\hline TSI-14 & Bacillus velezensis & ++ & & & ++ \\
\hline MSI-1 & Arthrobacter oxydans & & & & \\
\hline MSI-6 & Bacillus velezensis & ++ & & & ++ \\
\hline MSI-9 & Bacillus subtilis & & & & \\
\hline MSI-11 & Arthrobacter nicotinovorans & & & & + \\
\hline MSI-15 & Paenibacillus polymyxa & + & & + & \\
\hline NSI-1 & Bacillus amyloliquefaciens & ++ & + & & ++ \\
\hline NSI-6 & Arthrobacter nicotinovorans & & + & & + \\
\hline NSI-7 & Bacillus megaterium & & & & \\
\hline TSII-7 & Bacillus pumilus & & + & & ++ \\
\hline TSII-8 & Paenibacillus barcinonensis & & & & \\
\hline TSII-13 & Bacillus bataviensis & & & & \\
\hline TSII-18 & Streptomyces mexicanus & ++ & & ++ & \\
\hline MSII-6 & Bacillus pumilus & & & + & ++ \\
\hline MSII-10 & Bacillus amyloliquefaciens & ++ & & & ++ \\
\hline MSII-14 & Paenibacillus polymyxa & + & + & + & \\
\hline NSII-3 & Streptomyces lincolnensis & & & & +++ \\
\hline NSII-11 & Bacillus amyloliquefaciens & ++ & & & ++ \\
\hline NSII-15 & Bacillus mycoides & & & & +++ \\
\hline NSII-16 & Bacillus subtilis & ++ & + & & ++ \\
\hline TSIII-14 & Paenibacillus alvei & ++ & + & & \\
\hline MSIII-3 & Bacillus megaterium & & & & \\
\hline NSIII-5 & Microbacterium foliorum & & & & \\
\hline NSIII-7 & Bacillus mycoides & & & + & \\
\hline NSIII-8 & Bacillus pumilus & & & & ++ \\
\hline NSIII-10 & Bacillus amyloliquefaciens & ++ & & & ++ \\
\hline NSIII-11 & Bacillus licheniformis & + & & & + \\
\hline NSIII-20 & Bacillus shandongensis & & & & \\
\hline
\end{tabular}

Symbol: -, not inhibited; +, weakly inhibited; ++, moderately inhibited; and +++, strongly inhibited respectively.

and P. ultimum. Likewise, B. velezensis isolates (TS I-14 and MS I-6) also had the same ability. The phytopathogens $P$. capsici and $R$. solani were found to be resistant to almost all the rhizobacterial isolates studied.

\section{Discussion}

The use of beneficial soil microorganisms as agricultural inputs for improved crop production requires selection of rhizosphere-competent microorganisms with plant growth promoting attributes. To attain this, we conducted the study and the results indicated a mixed composition of rhizobacterial communities recovered from the ginseng rhizosphere of varying age levels. About 143 different isolates belonging to 15 different bacterial genera have been identified in this study.
Several studies on rhizobacteria in the rhizosphere of rice, wheat and other agronomically important crops have been performed previously (Hynes et al., 2008; Joshi and Bhatt, 2011; Joshi et al., 2011). Sequencing of 16S rRNA genes revealed the presence of rhizobacteria in ginseng belonging to Firmicutes, Actinobacteria, $\beta$-Proteobacteria, and $\gamma$-Proteobacteria. In our study, majority of rhizobacteria were Firmicutes (58\%) which included Bacillus and Paenibacillus. Firmicutes are gram positive bacteria with low $\mathrm{G}+\mathrm{C}$ content and they constitute one of the main phyla within the Bacteria. The dominance of Firmicutes in the rhizobacterial community composition was also observed earlier by many workers (Han et al., 2009; Pereira et al., 2011; Lee et al., 2012).

The present data suggest that Bacillus was the predominant genus found in Firmicutes. Various workers reported the 
dominance of Bacillus in rhizosphere of crops like potato (Calvo et al., 2010), rice (Joshi et al., 2011), and Eleagnus (Ramos et al., 1998). The preponderance of Bacillus is due to its ability to use the nutrients efficiently provided by the plant exudates. Many strains of Bacillus have been reported to produce substances that act as growth inhibitors for other organisms (Bai et al., 2002; Sadfi et al., 2002). Above all, the endospore forming ability of Bacillus makes the genus more stable in the competitive and dynamic rhizosphere. Our present study clearly indicated that age of the plant could largely influence the variation in rhizobacterial community of ginseng plants. It is apparent that the actual composition of the microbial community in the root zone is dependent on root type, plant species and age of the plant (Lugtenberg and Kamilova, 2009; Joshi et al., 2011). Our previous work on endophytic bacteria in the ginseng also suggested that the age of the plant could alter the endophytic community in the ginseng roots (Vendan et al., 2010). Many workers cite Pseudomonas of $\gamma$-Proteobacteria as the dominant genera in the rhizosphere of many crops. In contrast, Bacillus of Firmicutes was the dominant genera in our study. Surprisingly, there was not even a single Proteobacterial member in the three year old ginseng soil. The negligible occurrence of Pseudomonas in the ginseng rhizosphere warrants further study.

Although the analysis of bacterial diversity by using culture techniques has its own limitation, its main advantage is that a number of bacterial strains can be isolated and characterized for further study. To assess the plant growth promoting potential, all the screened strains were subjected to the above mentioned assays. Production of fungal cell wall degrading enzymes was analyzed because this is an important mechanism of fungal inhibition (Chang et al., 2007). The isolates viz., B. mycoides, $B$. amyloliquefaciens, and B. velezensis were found to produce protease, cellulase and xylanase in appreciable amount and this is in agreement with the previous work (Chaiharn and Lumyong, 2009). The capacity to synthesize IAA is widespread among soil-and plant-associated bacteria. All the tested isolates produced IAA, however most of them synthesized only low amount. Although low IAA production was noticed by majority of our strains, it has been shown that even low concentrations can induce an increase in the radical length and number of secondary roots, and not always high concentrations result in a better growth promotion (Selvadurai et al., 1991).

Siderophores provide a competitive advantage to producer organisms over fungal pathogens for the absorption of available iron. Our data suggest that isolates derived from three year old ginseng rhizosphere showed siderophore activity when compared to early periods. It might be due to the iron requirement of aged plants as compared to young ones. The potential to produce siderophores by microorganisms in improving iron availability to plants was also reported by many workers (Rroco et al., 2003; Sharma et al., 2003). Phosphate solubilization is considered to be the most important attribute of plant growth promoting rhizobacteria (Lugtenberg and Kamilova, 2009). Several microorganisms are able to make insoluble soil phosphorus available to plants through the production of organic and inorganic acids. Majority of our isolates solubilised the bound form of phosphates and it was similar to those reported on phosphate solubilization (Nautiyal, 1999; Vessey, 2003; Chatli et al., 2008).

The potential to use of rhizobacteria for biocontrol to protect crops from fungal diseases has investigated in this study. Many of our bacterial strains had no antifungal effects. But few isolates, B. subtilis, B. amyloliquefaciens, and B. velezensis showed antifungal activity against most of the pathogens tested. Many species of Bacillus are known to suppress several fungal pathogens and various studies on the antifungal activities of rhizobacteria have been performed (Lee et al., 2003; Hynes et al., 2008). The antifungal antibiotics and peptides including mycobacillins, bacillomycins, fungistatins produced by Bacillus species (Sadfi et al., 2002) seem to play major role in the biological control of plant pathogens.

In conclusion, this study provides a picture of the rhizobacterial community associated with ginseng growing in Korea. Most of the isolates belong to Bacillus of Firmicutes and the age of the plant could largely influence the variation in bacterial community of ginseng rhizosphere. The findings of the present investigation highlighted that some of the isolates could exhibit multiple plant growth promoting traits like secretion of cell wall degrading enzymes, production of IAA, synthesis of siderophores, solubilization of phosphates and antifungal activity against pathogens. Looking at the data, it can be suggested that strains of B. subtilis, B. amyloliquefaciens, $B$. velezensis, and $B$. lichiniformis were positive for all the above traits and they are the best candidates to develop bioinoculants consortium for ginseng. Future studies will examine the effects of these bacteria on ginseng plants under different growth conditions.

\section{적 요}

연령을 달리하는 인삼토양 내 근권세균의 다양성과 이들 세 균이 갖고 있는 식물생장에 유용한 특성에 대하여 조사하였다. 인삼 근권으로부터 총 15 개 속에 포함되는 143 균주를 분리하였 다. 인삼 연령에 따른 세균 군집의 변화가 있었으나, 분리 균주의 $58 \%$ 가 Firmicutes에 속하였다. 특히 Bacillus는 연령에 관계없이 가장 우점하는 속으로 나타났다. 이들 분리 균주 중 30 개의 균주 를 선발하여 세포벽 분해효소 분비, 인돌아세트산 생성, siderophore 
생성, 인 가용화, 식물병원성 곰팡이의 저해능 등에 대하여 평가한 결과, 다수의 균주가 식물생장을 촉진할 수 있는 기능적 특성을 갖고 있었다. 이 중에서도 모든 조사 항목에 대하여 양성 반응을 보 인 B. subtilis, B. amyloliquefaciens, B. velezensis, B. licheniformis 균주는 향후 인삼 경작을 위한 생장 촉진 미생물제제로 활용가 치가 높을 것으로 기대된다.

\section{Acknowledgements}

This work was supported by the grant from the MVP AgTec Company. Hong EH and Lee SH were supported by the BK21 Project.

\section{References}

Bai, Y., Frederic, D.A., Donald, L.S., and Brian, T.D. 2002. Isolation of plant-growth-promoting Bacillus strains from soybean root nodules. Can. J. Microbiol. 48, 230-238.

Bashan, Y., Holguin, G., and de-Bashan, L.E. 2004. Azospirillum-plant relationships: physiological, molecular, agricultural, and environmental advances. Can. J. Microbiol. 50, 521-577.

Banchio, E., Bogino, P.C., Zygadlo, J., and Giordano, W. 2008. Plant growth promoting rhizobacteria improve growth and essential oil yield in Origanum majorana L. Biochem. Syst. Ecol. 36, 766-771.

Calvo, P., Orillo, E.O., Romero, E.M., and Zuniga, D. 2010. Characterization of Bacillus isolates of potato rhizosphere from Andean soils of Peru and their potential PGPR characteristics. Braz. J. Microbiol. 41, 899-906.

Chaiham, M. and Lumyong, S. 2009. Phosphate solubilization potential and stress tolerance of rhizobacteria from rice soil in Northern Thailand. World J. Microbiol. Biotechnol. 25, 305-314.

Chang, W.T., Chen, Y.C., and Jao, C.L. 2007. Antifungal activity and enhancement of plant growth by Bacillus cereus grown on shellfish chitin wastes. Bioresour. Technol. 98, 1224-1230.

Chatli, A.S., Beri, V., and Sidhu, B.S. 2008. Isolation and characterisation of phosphate solubilising microorganisms from the cold desert habitat of Salix alba Linn. in trans Himalayan region of Himachal Pradesh. Indian J. Microbiol. 48, 267-273.

Goldstein, A.H. 1986. Bacterial solubilization of mineral phosphates: historical perspective and future prospects. Am. J. Alter. Agric. 1, 51-57.

Han, J., Xia, D., Li, L., Sun, L., Yang, K., and Zhang, L. 2009. Diversity of culturable bacteria isolated from root domains of Moso Bamboo (Phyllostachys edulis). Microb. Ecol. 58, 363-373.

Hartmann, A., Singh, M., and Klingmueller, W. 1983. Isolation and characterization of Azospirillum mutants excreting high amounts of indole acetic acid. Can. J. Microbiol. 29, 916-923.

Hynes, R.K., Leung, G.C., Hirkala, D.L., and Nelson, L.M. 2008. Isolation, selection, and characterization of beneficial rhizobacteria from pea, lentil, and chickpea grown in western Canada. Can. J. Microbiol. 54, 248-258.

Joshi, P. and Bhatt, A.B. 2011. Diversity and function of plant growth promoting rhizobacteria associated with wheat rhizosphere in North Himalayan region. Int. J. Environ. Sci. 1, 1135-1143.

Joshi, P., Tyagi, V., and Bhatt, A.B. 2011. Characterization of rhizobacteria diversity isolated from Oryza sativa cultivated at different altitude in North Himalaya. Adv. Appl. Sci. Res. 4, 208-216.
Lee, C.S., Kim, K.D., Hyun, J.W., and Jeun, Y.C. 2003. Isolation of rhizobacteria in Jeju island showing anti-fungal effect against fungal plant pathogens. Mycobiol. 31, 251-254.

Lee, S., Ka, J.-O., and Song, H.-G. 2012. Growth promotion of Xanthium italicum by application of rhizobacterial isolates of Bacillus aryabhattai in microcosm soil. J. Microbiol. 50, 45-49.

Lugtenberg, B. and Kamilova, F. 2009. Plant-growth-promoting rhizobacteria. Annu. Rev. Microbiol. 63, 541-556.

McGinnis, S. and Madden, T.L. 2004. BLAST: at the core of a powerful and diverse set of sequence analysis tools. Nucleic Acids Res. 32, 20-25.

Nautiyal, C.S. 1999. An efficient microbiological growth medium for screening phosphate solubilizing microorganisms. FEMS Microbiol. Lett. 170, 265-270.

Noura, R., Ameur, C., Abdellatif, B., and Daniele, D. 2008. Screening of plant growth promoting traits of Bacillus thuringiensis. Ann. Microbiol. 58, 47-52.

Pereira, P., Ibanez, F., Rosenblueth, M., Etchevery, M., and MartinezRomero, E. 2011. Analysis of the bacterial diversity associated with the roots of Maize (Zea mays L.) through culture-dependent and culture-independent methods. ISRN Ecology, Volume 2011, Article ID 938546, 10 pages, doi:10.5402/2011/938546.

Ramos, B., Pozuelo, J.M., Acero, N., and Gutierrez Manero, F.J. 1998. Seasonal variation of Bacillus isolates from the rhizosphere of Elaeagnus angustifolia L. Orsis. 13, 7-16.

Rroco, E., Kosegarten, H., Harizaj, F., Imani, J., and Mengel, K. 2003. The importance of soil microbial activity for the supply of iron to sorghum and rape. Europ. J. Agron. 19, 487-493.

Sadfi, N., Cherif, M., Hajlaoui, M.R., Boudabbous, A., and Belanger, R. 2002. Isolation and partial purification of antifungal metabolites produced by Bacillus cereus. Ann. Microbiol. 52, 323-337.

Schwyn, B. and Neilands, J.B. 1987. Universal chemical assay for the detection and determination of siderophores. Anal. Biochem. 160, 47 -56 .

Selvadurai, E.L., Brown, A.E., and Hamilton, J.T.G. 1991. Production of indole-3-acetic acid analogues by strains of Bacillus cereus in relation to their influence on seedling development. Soil Biol. Biochem. 23, 401-403.

Sharma, A., Johri, B.N., Sharma, A.K., and Glick, B.R. 2003. Plant growth promoting bacterium Pseudomonas sp., strain GRP3 influences iron acquisition in mung bean (Vigna radiate L. Wilzeck). Soil Biol. Biochem. 35, 887-894.

Tamura, K., Dudley, J., Nei, M., and Kumar, S. 2007. MEGA4: Molecular Evolutionary Genetics Analysis (MEGA) software version 4.0. Mol. Biol. Evol. 24, 1596-1599.

Tompson, J.D., Higgins, D.G., and Gibson, T.J. 1994. CLUSTAL W: improving the sensitivity of progressive multiple sequence alignment through sequence weighting, position-specific gap penalties and weight matrix choice. Nucleic Acids Res. 22, 4673-4680.

Vendan, R.T., Yu, Y.J., Lee, S.H., and Rhee, Y.H. 2010. Diversity of endophytic bacteria in ginseng and their potential for plant growth promotion. J. Microbiol. 48, 559-565.

Vessey, J.K. 2003. Plant growth promoting rhizobacteria as biofertilizers. Plant Soil 255, 571-586.

Yang, J., Kloepper, J.W., and Ryu, C.M. 2009. Rhizosphere bacteria help plants tolerate abiotic stress. Trends Plant Sci. 14, 1-4.

Yu, W.J., Lee, B.J., Nam, S.Y., Yang, D.C., and Yun, Y.W. 2003. Modulating effects of Korean ginseng saponins on ovarian function immature rats. Biol. Pharm. Bull. 26, 2574-2580. 